\title{
The influence of probiotic additives or multienzyme composition on blood biochemical parameters and milk quality of Lithuanian Black-and-White cattle
}

\author{
[Influencia de aditivos probióticos ou composições multienzimáticas em parâmetros bioquímicos \\ séricos e volume de leite em gado Preto-e-Branco da Lituânia \\ J. Dailidavičienè, R. Budreckienè, R. Gružauskas, S. Kerzienè, V. Andrulevičiūtè, I. Sinkevičienè
}

Lithuanian University of Health Science - Kaunas, Lithuania

\begin{abstract}
The aim of the study was to determine the effect of Saccharomyces cerevisiae, multienzyme composition supplementation on milk yield, quality, blood biochemical parameters of Lithuanian-Black-and-White cows. For this reason 28 cows were divided into four groups (three experimental and one control) each with seven cows fed balanced ration (control group) and following experimental groups: addition of $40 \mathrm{~g}$ supplement of live yeast with organic selenium (group A); 40g supplement of live yeast with aromatic additives (group B); and $0.2 \mathrm{~g}$ supplement of multienzyme composition (group C) during a 90 days period. The study showed that milk yield was $2.64 \%, 1.75 \%, 1.4 \%$ higher in groups A, B, C respectively, comparing with the control group. The milk SCC in experimental groups were lower comparing to the control group. The percentage of milk fat was significantly higher in group $\mathrm{A}-0.33 \%, \mathrm{~B}-0.31 \%$ and $\mathrm{C}-0.16 \%$ comparing with the control group. All used additives ensure positive dynamics of investigated biochemical parameters in cattle blood. The results indicated that probiotic additives and multienzyme composition supplementation to dairy cows increased cows productivity and milk fat as well. Probiotic additives supplementation decreased SCC values in milk.
\end{abstract}

Keywords: dairy cow, probiotic, yeast, milk yield, blood

\section{RESUMO}

O objetivo do estudo foi determinar o efeito de Saccharomyces cerevisiae, suplementação multienzimática na produção e qualidade de leite e em parâmetros séricos bioquímicos de vacas Preto e Brancas da Lituânia. Vinte oito vacas foram dividias em quatro grupos (três experimentais e um controle) cada um com sete vacas alimentadas com ração balanceada (grupo controle) e os grupos experimentais com: adição de $40 \mathrm{~g}$ de suplemento de fermento vivo com selênio orgânico (grupo A); $40 \mathrm{~g}$ de fermento vivo com aditivos aromaticos (grupo B); e $0.2 \mathrm{~g}$ de suplemento multienzimático (grupo C) durante 90 dias. O estudo demonstrou que produção de leite foi 2,65\%, 1,75\%, e 1.4\% mais alto nos grupos $A, B, C$ respectivamente, quando comparados ao grupo controle. A porcentagem de gordura no leite foi significativamente maior no grupo $A-0,33 \%, B-0,31 \%$, e C-0,16\% em comparação ao grupo controle. Todos os aditivos asseguraram dinâmica positiva para parâmetros bioquímicos séricos na amostra estudada. Os resultados indicaram que aditivos probióticos e de composição multienzimática em dieta de vacas leiteiras aumentou produtividade e gordura do leite. Suplementação com aditivos probióticos reduz valores de SCC em leite.

Palavras-chave: vaca leiteira, probiótico, fermento, produção de leite, sangue

\section{INTRODUCTION}

Lithuanian Black-and-White cattle account for about $60 \%$ of bred cattle in Lithuania. Improving the breed, the most important tasks are to increase the milk production, milk fat and protein

Recebido em 10 de novembro de 2016

Aceito em 25 de março de 2017

E-mail: jurgita.dailidaviciene@1smuni.1t content; to improve the udder morphological and physiological characteristics and to preserve meat quality (Maamouri et al., 2014, Szucs et al., 2013). The most important factor in development of these qualities is feed. The fodder enrichment with various additives is consequently very important and useful. 
Carotenoids are present in animal systems, but animals cannot synthesize them de novo and depend on intake from their feed. However feed does not always provide optimal ecosystem functioning of cattle rumen. Currently, for the regulation of digestive tract the biologically active microbial preparations are used not only as a way for improvement of physiological functions of animal, but also as material that antagonistically affect patogenic microflora (Ibrahim et al., 2010). Use of yeast culture as a dietary supplement has been suggested as a useful tool to stabilize ruminal fermentation based on several in vitro and in vivo research. Yeast culture products contain Saccharomyces cerevisiae fermentation metabolites (B vitamins, amino acids, organic acids) and may have a number of effects in the rumen including increased $\mathrm{pH}$, altered volatile fatty acids concentrations (Williams et al., 1991, Szucs, 2013) and also increased numbers of cellulolytic bacteria (Callaway and Martin, 1997, Szucs et al., 2013). The probiotic additives of live yeast cultures (Saccharomyces cerevisiae) with organic selenium have been added to diets for lactating dairy cows to attempt to improve ruminal fermentation, potentially increasing dry matter intake and milk yield (Ayad et al., 2013, Maamouri et al., 2014). Selenium plays a crucial and ubiquitous role in the organism. The health benefits of selenium supplementation in ruminants are well recognized. In dairy cows, this is directly reflected by the potential of selenium supplementation to reduce somatic cell count (SCC) in milk and prevent sub-clinical mastitis (Eulogio et al., 2012, Pirestani et al., 2013). A universal multienzyme composition increases productivity, feed energy exchange, and digestibility of protein and amino acids (Kalmus et al., 2009, Yalçın et al., 2011); improves feed conversion, and reduces viscosity of the digestive tract and the incidence of diarrhea.

The aim of the study was to determine the effect of Saccharomyces cerevisiae and multienzyme composition supplementation on milk yield quality and on blood biochemical parameters of Lithuanian-Black-and-White cows.

\section{MATERIAL AND METHODS}

The effects of Saccharomyces cerevisiae and multienzyme composition supplementation of 28
Lithuanian Black-and-White diary cows in their third lactation at the beginning of the lactation cycle were investigated. All groups were uniform and raised at the same feeding and housing conditions in the experiment. Each cow daily ration contained perennial grass haylage $-40 \mathrm{~kg}$, corn silage $-12 \mathrm{~kg}$, grass silage $-20 \mathrm{~kg}$, wheat straw $-2 \mathrm{~kg}$, rapeseed pomace $-2,5 \mathrm{~kg}$, dry molasses - 200g, compound concentrates for milking cows $-4,5 \mathrm{~kg}$, salt $-100 \mathrm{~g}$, calcium carbonate $-150 \mathrm{~g}$. Animals were divided into three experimental groups (A, B, C) and control group containing of seven cows each group. The groups were fed a balanced ration and addition of $40 \mathrm{~g}$ supplement of additive with Saccharomyces cerevisiae CNCM I-1077 and organic selenium (group A); $40 \mathrm{~g}$ supplement of additive Saccharomyces cerevisiae CNCM I-1077 and aromatic additive (group B) and $0.2 \mathrm{~g}$ supplement of multienzyme additive (group C). Both probiotic additives - are multifunctional feed additives for ruminants containing the live Saccharomyces cerevisiae CNCM I-1077 (5×10 ${ }^{11}$ $\mathrm{CFU} / \mathrm{kg}$ ) and organic selenium (40mg/kg). Additionally probiotic additive in the group B contains aromatic additive $(0.02 \%)$, zinc oxide $(0.07 \%)$, sodium chloride $(30 \%)$ and rapeseed oil (1.5\%). As aromatic additive Pan Tutti Frutti Mix flavour additive was used. Enzymes for the group $\mathrm{C}$ were a universal multienzyme composition, consisting of various enzymes that are expected to break down all the non-starch polysaccharides and oligosaccharides of grain raw materials, soybean, sunflower and rapeseed meal. Multienzyme composition contains endo-xylanase $(90000 \mathrm{U} / \mathrm{g})$, endocellulase (12500U/g), endo-beta-glucanase $(33000 \mathrm{U} / \mathrm{g})$, endo-mannanase $(16000 \mathrm{U} / \mathrm{g})$.

Milk samples were analysed every 30 days during the 90 days period. Milk analyses were carried out in SE "Pieno tyrimai". An individual milk sample from individual quarters was taken once a month. Milk samples were collected for laboratory examination aseptically in accordance with the method recommended by the Milk and milk products. Guidance on sampling (ISO 707:2008)“" standard and analyzed in order to determine the fat $(\%)$, protein $(\%)$, urea $(\mathrm{mg} / 100 \mathrm{ml})$ and somatic cell count using the testing device "LactoScope FTIR" (FT1.0. in 2001, Delta Instruments, Netherlands). SCC was determined using a device "SomaScope" (CA3A4, 2004, Delta Instruments, Netherlands). 
Blood samples were investigated in the National Food and Veterinary Risk Assessment Institute. Samples were taken from the jugular vein into vacuum tubes containing 150 USP units of lithium heparin (Vacutainer; Becton, Dickinson and Co., Franklin Lakes, NJ) before cows feeding. At the laboratory, blood samples were centrifuged at $1,500 \times g$ for $10 \mathrm{~min}$ (Labofugel Gl, Heraeus Christ, Belgium). Plasma samples were analyzed using automatic biochemical analyzer "COBAS INTEGRA 400 plus" (Tegimenta Ltd. Roche, Switzerland). Amount of minerals (calcium, phosphorus and magnesium), total blood proteins, carotene and reserve alkalinity were determined. Carotene in blood serum samples was determined using spectrophotometric method (Genesys 6 spectrophotometer, Thermo Spectronic, USA), reserve alkalinity - by volumetric method.

Statistical analysis was performed using SPSS Statistic Version 20. The measures used were arithmetic mean of one random variable (M) and standard deviation. In order to compare milk and blood parameters between groups, a one-factor analysis of variance (ANOVA) was applied. The differences between the means were evaluated Fisher's LSD criterion. Student's t-test was used to find statistical differences between groups. Differences at the value of $\mathrm{P}<0.05$ were considered significant.

The work was performed in compliance with Lithuanian animal welfare regulations and was approved by the Lithuanian Committee of Veterinary Medicine and Zootechnics Sciences.

\section{RESULTS}

In this study live yeast and multienzyme composition supplementation to dairy cows significantly increased milk production in all milking periods. The changes in milk yield and milk fat over time are illustrated in Table 1. Milk yield was $2.64 \%, 1.75 \%$ and $1.4 \%$ higher in groups A and B respectively comparing to the control group.

As shown in Table 1, the highest milk yield was in group A at 60 days of experiment and differed from the control group statistically significant $(\mathrm{P}<0.01)$. During the study milk yield increased in all experimental groups, while it decreased in control group and was $0.48 \%$ lower at the end of the study comparing to the beginning. The highest milk yield was observed at 90 days of groups $\mathrm{A}$ and $\mathrm{B}$ and from the beginning of the study differed $2.71 \%$ and $2.58 \%$ respectively. The highest milk yield values evaluated in A group at 60 day of experiment $(\mathrm{P}<0.05)$. However, milk yield in A group was higher at the 30 day $(\mathrm{P}<0.01)$ and at the 90 day $(\mathrm{P}<0.01)$ of experiment comparing to the control group. At the end of the study milk yield in A and B groups was higher $3.62 \%(\mathrm{P}<0.01)$ and $2.95 \%(\mathrm{P}<0.05)$ respectively than in control group. As shown in Table 2, milk proteins did not change significantly with yeast and multienzyme composition supplementation and the dynamic of milk proteins changed fractionally. Milk urea amounts also increased in A and B groups at the end of study while it decreased in $\mathrm{C}$ group. Nevertheless it was not statistically significant between all groups.

Table 1. The average values of milk yield $(\mathrm{kg})$ and milk fat $(\%)$ of cows of control and every experimental group after $0,30,60,90$ days

\begin{tabular}{|c|c|c|c|c|c|c|c|c|}
\hline & \multicolumn{4}{|c|}{ Milk yield (kg) } & \multicolumn{4}{|c|}{ Milk fat (\%) } \\
\hline & $\begin{array}{l}\text { Control } \\
\text { group }\end{array}$ & Group A & Group B & Group C & $\begin{array}{l}\text { Control } \\
\text { group }\end{array}$ & $\begin{array}{c}\text { Group } \\
\text { A }\end{array}$ & $\begin{array}{c}\text { Group } \\
\text { B }\end{array}$ & $\begin{array}{c}\text { Group } \\
\text { C }\end{array}$ \\
\hline \multirow{2}{*}{0 days } & $24.57 \pm$ & $25.03 \pm$ & $24.46 \pm$ & $24.86 \pm$ & $4.35 \pm$ & $4.42 \pm$ & $4.29 \pm$ & $4.49 \pm$ \\
\hline & 0.37 & 1.10 & 0.88 & 0.86 & 0.12 & 0.13 & 0.12 & 0.14 \\
\hline \multirow{2}{*}{30 days } & $24.67 \pm$ & $27.57 \pm$ & $26.57 \pm$ & $26.43 \pm$ & $4.44 \pm$ & $4.82 \pm$ & $4.86 \pm$ & $4.58 \pm$ \\
\hline & 0.44 & $0.81 * *$ & $0.67 *$ & 0.57 & 0.14 & $0.08 *$ & $0.08 *$ & 0.16 \\
\hline \multirow{2}{*}{60 days } & $24.36 \pm$ & $27.93 \pm$ & $26.60 \pm$ & $26.03 \pm$ & $4.46 \pm$ & $4.85 \pm$ & $4.89 \pm$ & $4.60 \pm$ \\
\hline & 0.60 & $0.66 * *$ & $0.66^{*}$ & 0.67 & 0.14 & $0.09 *$ & $0.11 *$ & 0.17 \\
\hline \multirow{2}{*}{90 days } & $24.09 \pm$ & $27.71 \pm$ & $27.04 \pm$ & $26.03 \pm$ & $4.41 \pm$ & $4.88 \pm$ & $4.86 \pm$ & $4.62 \pm$ \\
\hline & 0.56 & $0.62 * *$ & $0.65^{*}$ & 1.46 & 0.15 & $0.06 * *$ & $0.05 * *$ & 0.12 \\
\hline
\end{tabular}

* - $\mathrm{P}<0.05 ; * *$ - $\mathrm{P}<0.01$ - average means differed significantly from control group. 
Table 2. The average values of milk proteins (\%) and milk urea ( $\mathrm{mg} \%)$ of cows of control and every experimental group after $0,30,60,90$ days

\begin{tabular}{ccccccccc} 
& \multicolumn{3}{c}{ Milk proteins (\%) } & \multicolumn{4}{c}{ Milk urea (mg/100ml) } \\
\cline { 2 - 9 } & $\begin{array}{c}\text { Control } \\
\text { group }\end{array}$ & $\begin{array}{c}\text { Group } \\
\text { A }\end{array}$ & Group B & $\begin{array}{c}\text { Group } \\
\text { C }\end{array}$ & $\begin{array}{c}\text { Control } \\
\text { group }\end{array}$ & Group A & Group B & $\begin{array}{c}\text { Group } \\
\text { C }\end{array}$ \\
\hline \multirow{2}{*}{0 days } & $3.13 \pm$ & $3.14 \pm$ & $3.12 \pm$ & $3.09 \pm$ & $16.14 \pm$ & $15.86 \pm$ & $13.71 \pm$ & $14.29 \pm$ \\
30 & 0.11 & 0.07 & 0.16 & 0.04 & 1.24 & 1.37 & 2.22 & 0.94 \\
days & $3.02 \pm$ & $3.16 \pm$ & $3.14 \pm$ & $3.02 \pm$ & $11.71 \pm$ & $12.14 \pm$ & $13.67 \pm$ & $10.43 \pm$ \\
60 & 0.12 & 0.07 & 0.17 & 0.03 & 1.30 & 1.40 & 0.99 & 1.04 \\
days & $0.13 \pm$ & $3.14 \pm$ & $3.18 \pm$ & $3.12 \pm$ & $14.86 \pm$ & $17.00 \pm$ & $14.57 \pm$ & $13.43 \pm$ \\
90 & $3.10 \pm$ & 0.06 & 0.10 & 0.06 & 1.74 & 1.70 & 1.78 & 1.45 \\
days & 0.12 & $0.02 \pm$ & $3.11 \pm$ & $3.10 \pm$ & $15.29 \pm$ & $16.00 \pm$ & $14.57 \pm$ & $14.17 \pm$ \\
\hline
\end{tabular}

The percentage of milk fat was significantly higher in cows of group $\mathrm{A}-0.33 \%, \mathrm{~B}-0.31 \%$ and $\mathrm{C}-0.16 \%$ comparing with the control group (Table 1). Milk fat of A and B groups at the end of experiment increased $0.46 \%$ and $0.57 \%$ respectively comparing to the data at the beginning of experiment. The largest milk fat concentration was found in group A after 90 day of supplementation of live yeast and was statistically significant comparing to the control group $(\mathrm{P}<0.01)$. For group $\mathrm{B}$ the biggest amount of milk fat was observed at 60 day of experiment and was statistically significant comparing to the control group $(\mathrm{P}<0.05)$; whereas milk fat in all groups increased at all experimental periods (Figure 1). Cows supplemented with ration of multienzyme group $\mathrm{C}$ milk fat increased at the end of experiment, however, when compared to the control group data differences were not statistically significant.

There were minimal dynamics of somatic cell counts (SCC) values in all other groups. The SCC in milk in all experimental groups were lower comparing to the control group (Figure 2). The highest SCC values was in B group at day 0 , and the lowest value in groups $\mathrm{A}$ and $\mathrm{C}$ at day 0 . SCC amounts changed comparing all experimental periods insignificantly while SCC in A group was 75.3 thousands/ml higher at the end of experiment than at the beginning. On the contrary in the B group - SCC values were higher 644.43 thousands/ml at the beginning of study than at the end. SCC in C group increased in all experimental periods.experimental periods insignificantly while SCC in A group was 75.3 thousands/ml higher at the end of experiment than at the beginning. On the contrary in the B group - SCC values were higher 644.43 thousands/ml at the beginning of study than at the end. SCC in $\mathrm{C}$ group increased in all experimental periods.

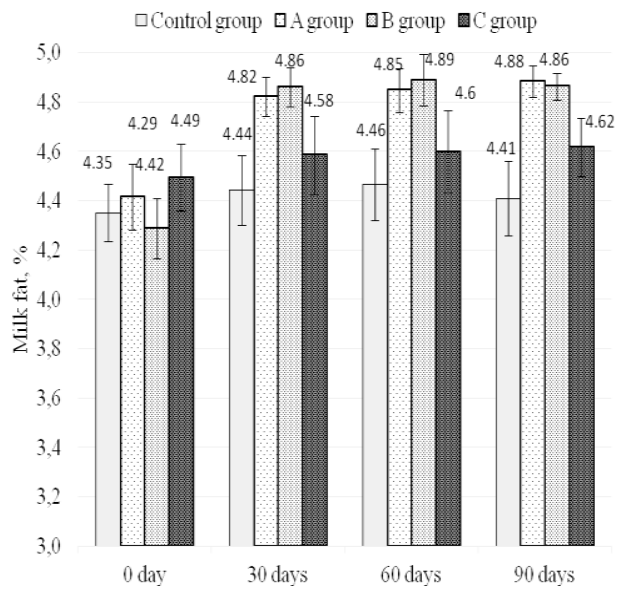

Figure 1. The dynamics of milk fat change (\%) in all groups during examined periods.

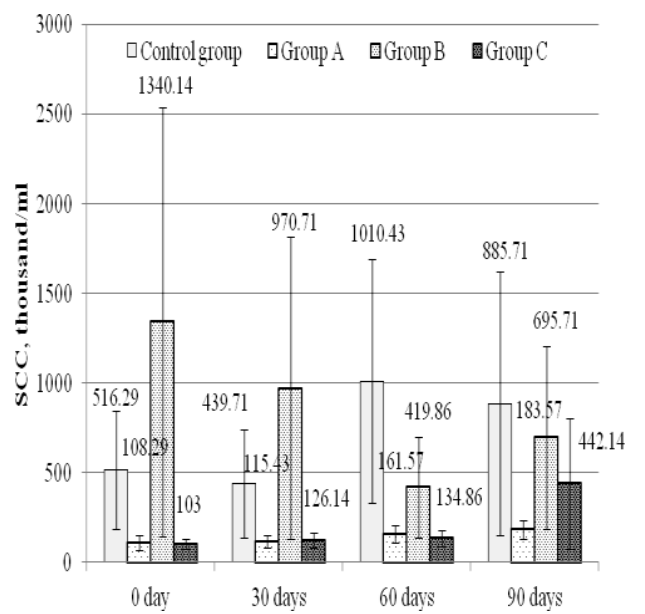

Figure 2. The dynamics of SCC (thousand $/ \mathrm{ml}$ ) in all groups during examined periods. 
Blood biochemical parameters in all experimental periods are presented in Table 3 . All used multifunctional additives for ruminants had a positive effect on the carotene concentrations in the cow's blood. From the data presented in Table 3 is evident, that amounts of both - carotene and $\mathrm{CO}_{2}$ evenly increased eliminating individual cases. The largest dynamics in the carotene concentrations was observed in all experimental groups at 90 days of ration supplementation with live yeast and multienzyme composition. The strongest effect is characterized to probiotic additive at the A group. The normal carotene concentration provides an adequate synthesis of vitamin $\mathrm{A}$, and thus the body's resistance. The amount of alkalinity reserve in the blood of investigated cows evenly changed. The highest $\mathrm{CO}_{2}$ values observed in group A after 60 days of supplementation additive with live yeast. The dynamics of both indicators in all experimental groups was smoother and more consistent with regard to the individual animal, comparing with the control group, but meets with the recommended analytical rates, which is especially important for the prevention of acidosis. Influence of feed additives for minerals (calcium, phosphorus, magnesium) concentration dynamic in the cattle blood was positive and evaluated in the normal physiological limits of concentrations.

Table 3. Effect of probiotic additives and multienzyme composition on cow's blood biochemical parameters

\begin{tabular}{ccccccccc} 
& \multicolumn{4}{c}{ The begining of the experiment $(0$ days $)$} & \multicolumn{3}{c}{ The end of the experiment $(90$ days) } \\
Parameter & Control & Group & Group & Group & Control & Group & Group & Group \\
& group & A & B & C & group & A & B & C \\
\hline Calcium, & $2.34 \pm$ & $2.51 \pm$ & $2.53 \pm$ & $2.39 \pm$ & $2.54 \pm$ & $2.51 \pm$ & $2.66 \pm$ & $2.67 \pm$ \\
mmol/l & $0.061 \mathrm{a}$ & 0.046 & 0.076 & $0.059 \mathrm{a}$ & $0.036 \mathrm{~b}$ & 0.062 & 0.048 & $0.039 \mathrm{~b}$ \\
Phos-phorus, & $1.93 \pm$ & $1.98 \pm$ & $1.91 \pm$ & $2.10 \pm$ & $2.21 \pm$ & $2.21 \pm$ & $2.29 \pm$ & $2.29 \pm$ \\
mmol/l & 0.124 & $0.044 \mathrm{a}$ & 0.204 & 0.108 & $0.085 \mathrm{~b}$ & $0.074 \mathrm{a}$ & $0.105 \mathrm{c}$ & 0.144 \\
Magnesium, & $0.85 \pm$ & $0.84 \pm$ & $0.81 \pm$ & $0.83 \pm$ & $0.95 \pm$ & $1.18 \pm$ & $0.93 \pm$ & $1.06 \pm$ \\
mmol/l & $0.04 \mathrm{a}$ & $0.017 \mathrm{a}$ & $0.052 \mathrm{abc}$ & $0.034 \mathrm{a}$ & $0.035 \mathrm{~d}$ & $0.101 \mathrm{~b}$ & $0.058 \mathrm{~d}$ & $0.073 \mathrm{~b}$ \\
Carotene, & $0.013 \pm$ & $0.014 \pm$ & $0.011 \pm$ & $0.011 \pm$ & $0.019 \pm$ & $0.021 \pm$ & $0.018 \pm$ & $0.018 \pm$ \\
mmol/1 & $0.001 \mathrm{a}$ & $0.001 \mathrm{a}$ & $0.001 \mathrm{a}$ & $0.002 \mathrm{a}$ & $0.001 \mathrm{~d}$ & $0.002 \mathrm{c}$ & $0.001 \mathrm{~d}$ & $0.001 \mathrm{~d}$ \\
Alkalinity & $45.31 \pm$ & $44.41 \pm$ & $46.72 \pm$ & $49.41 \pm$ & $54.46 \pm$ & $57.47 \pm$ & $50.81 \pm$ & $53.61 \pm$ \\
reserve, $\%$ & $2.039 \mathrm{a}$ & $0,803 \mathrm{a}$ & $2.073 \mathrm{a}$ & $1.606 \mathrm{acb}$ & $1.915 \mathrm{~b}$ & $1.940 \mathrm{~b}$ & 2.686 & $1.838 \mathrm{~d}$ \\
Total & $75.24 \pm$ & $71.93 \pm$ & $74.41 \pm$ & $75.24 \pm$ & $81.89 \pm$ & $76.07 \pm$ & $80.59 \pm$ & $80.14 \pm$ \\
proteins & $1.070 \mathrm{acd}$ & $0.829 \mathrm{ac}$ & $1.725 \mathrm{acd}$ & $1.070 \mathrm{a}$ & $3.462 \mathrm{db}$ & $0.829 \mathrm{bd}$ & $2.721 \mathrm{db}$ & $1.148 \mathrm{dab}$ \\
\hline
\end{tabular}

a,b,c,d averages differed statistically significant $(\mathrm{P}<0.05)$.

\section{DISCUSSION}

There are several studies that evaluate yeast supplementation on dairy cows productivity whereas results are contradictory. In some studies, yeast cultures improved milk production. The experiment of Moallem et al. (2009) milk yield increased by $1.5 \mathrm{~kg}(4.1 \%)$ with live yeast supplemention. According to the Szucs et al. (2013) the best yield was reached by the treated primiparous cows but no important difference was found between the daily yield of treated and control multiparous cows. Arambel and Kent (1990) found a little or no response to yeast cultures for the milk yield and milk composition. While others report opposite findings - milk yield decreases in supplementation with live yeast (Bertrand and Grimes, 1997; Schwartz et al., 1994). Several studies (Robinson and Garrett, 1999; Dann et al., 2000, Yalçın et al., 2011) have shown that live yeast and yeast culture supplementation may increase feed intake and milk production of dairy cows. Some researchers (Robinson and Garrett, 1999; Dann et al., 2000; Erasmus et al., 1992, Yalçın et al., 2011) have suggested that feeding yeast products may be most beneficial to dairy cows during late gestation and early lactation because of their effects on rumen fermentation and nutrient digestion. It is quite difficult to explain causes of these different results, but the reason for such differences might be the various effect of yeast and cows physiological conditions. Our results showed positive effects of probiotic additives to cows productivity. Live yeast seems to activate fermentative processes in rumen and determine 
more stable milk production. Also live yeasts may enhance the rumen environment by scavenging free oxygen, as evidenced by a lower redox potential in the rumen (Chaucheyras et al., 2002, Szucs et al., 2013). According to Szucs et al. (2013) milk fat and the milk protein content of treated cows decreased to a less degree but the difference was not significant compared to the control group. The results of Maamouri et al. (2014) showed that supplementation with yeast Saccharomyces cerevisiae tended to increase milk production by $1.1 \mathrm{~kg}$ per cow. But no changes were noted for milk composition. In contrary our results indicated feed additive positive effects to milk composition.

One of the most important milk qualitative indicators - a somatic cell count showed that probiotic additives and multenzyme composition hadn't significant influence on SCC values in milk and was inherent to Lithuanian Black-andWhite cows (Juozaitienè et al., 2004). The minimal SCC change in milk probably could be due to milk yield changes. According to Aniulis et al. (2000) when milk production is decreased, the SCC in milk is increasing.

Pirestani et al. (2013) results showed that selenium treatment group resulted in low SCC in milk. These findings might be due to an increase in the activity of polymorphonuclear neutrophils (PMN), immune potency and resistance of the animal against infectious diseases. Also, Se is a constructional part of glutathione peroxidase structure and acts as an important biological antioxidant, which prevents the activity of free radicals leading to the udder health and milk quality (Pirestani et al., 2013). Our study results corresponds to Piretani et al. (2013) data and showed that Se supplementation improved milk yield and fat and also reduced SCC values in milk.

Aromatic additives have been documented to improve nutrient digestibility in swine (Maenner et al., 2011) and in poultry (Basmacioglu Malayoglu et al., 2010). We think that aromatic additives are often claimed to improve the flavor and palatability of feed, thus increasing voluntary feed intake resulting in improved productivity.

Our study results showed that multienzyme composition supplementation improved milk production and increased SCC in milk. These results correspond to those reported by Dean et al. (2013).

Carotene is a major source of vitamin A. It's absorption takes place in the small intestine. Only a third or a quarter of a feed-carotene could be absorbed, and just seventh of mastered carotene is converted into vitamin $\mathrm{A}$. Hypocarotinemia is one of the reasons of the body's resistance, reduced productivity and reproduction troubles, while too overwhelming concentration of carotene is harmless to body the excess is transformed into vitamin A. The alkalinity reserve - especially important indicator for acidosis/alkalosis diagnosis. The reduction in this ratio (which often happens because of specific ruminant metabolism) raises the risk of acidosis, while the increase - the threat of alkalosis. Ruminants are animals suffering from acidosis, for which prevention maintaining of alkalinity reserve in the recommended range - is very important. Feed additives positively affects the activity of rumen and improves digestive function through positive dynamic of biochemical blood parameters, therefore organism assimilates more necessary materials. Established concentration of $\mathrm{CO}_{2}$ shows that rumen environment is stabilized and cows do not suffer from acidosis or ketosis. The obtained results are within the normal range of recommended levels and are higher to compare with results of the control group. The equivalent increase in alkalinity reserve and the concentration of carotene observed leads to improved animal well-being and positive synthesis of vitamin A.

\section{CONCLUSION}

All the used additives ensure the positive dynamics of investigated biochemical parameters in cattle blood. The results indicated that probiotic additives and multienzyme composition supplementation to dairy cows increased cows productivity and milk fat as well. Probiotic additives supplementation decreased SCC values in milk.

\section{ACKNOWLEDGEMENTS}

This study was made possible through the kind support of JSC „Baltijos enzimai“ and access to the animals in the Practical Training and Testing Centre of Lithuanian University of Health Sciences. 


\section{REFERENCES}

AYAD, M.A.; BENALLOU, B.; SAIM, M.S. et al. Impact of feeding yeast culture on milk yield, milk components, and blood components in Algerian dairy herds. J. Vet. Sci. Tech., v.4, p.1-5, 2013.

ANIULIS, E.; JAPERTAS, S.; LEIPUTĖ, K. Karviu pieno kokybės analizė, atsižvelgiant ì somatinių ląstelių skaičių. Vet. Zootec., v.8, p.5-8, 2000.

ARAMBEL, M.J.; KENT, B.A. Effect of yeast culture on nutrient digestibility and milk yield response in early to midlactation dairy cows. J. Dairy Sci., v.73, p.1560-1563, 1990.

BASMACIOGLU MALAYOGLU, H.; BAYSAL, S.; MISIRLIOGLU, Z. et al. Effects of oregano essential oil with or without feed enzymes on growth performance, digestive enzyme, nutrient digestibility, lipid metabolism and immune response of broilers fed on wheat-soybean meal diets. Br. Poult. Sci., v.51, p.67-80, 2010.

BERTRAND, J.A.; GRIMES L.W. Influence of tallow and Aspergillus oryzae fermentation extract in dairy cattle rations. J. Dairy Sci., v.80, p.1179-1184, 1997.

CALLAWAY, E.S.; MARTIN, S.A. Effects of a Saccharomyces cerevisiae culture on ruminal bacteria that utilize lactate and digest cellulose. J. Dairy Sci., v.80, p.2035-2044, 1997.

CHAUCHEYRAS E.; DURAND F.G.; FONTY G. Influence of a probiotic yeast (Saccharomyces cerevisiae NCM I-1077) on microbial colonization and fermentations in the rumen of newborn lambs. Microb. Ecol. Health Dis., v.14, p.30-36, 2002.

DANN, H.M.; DRACKLEY, J.K.; MCCOY, G.C. et al. Effects of yeast culture (Saccharomyces cerevisiae) on prepartum intake and postpartum intake and milk production of Jersey cows. J. Dairy Sci., v.83, p.123-127, 2000 .

DEAN, D.B.; STAPLES, C.R.; LITTELL, R.C. et al. Effect of method of adding a fibrolytic enzyme to dairy cow diets on feed intake digestibility, milk production, ruminal fermentation, and blood metabolites. Anim. Nutr.Feed Technol., v.13, p.337-353, 2013

ERASMUS L.J.; BOTHA P.M.; KISTNER A. Effect of yeast culture supplement on production, rumen fermentation, and duodenal nitrogen flow in dairy cows. J. Dairy Sci., v.75, p.3056-3065, 1992.

EULOGIO G.L.J.; HUGO C.V.; ANTONIO C.N.; ALEJANDRO C.I.; JUAN M.Q. Effects of the selenium and vitamin $\mathrm{E}$ in the production, physicochemical composition and somatic cell count in milk of Ayrshire cows. J. Anim. Vet. Adv. v.11, p.687-691, 2012.

YALÇIN, S.; YALÇIN, S.; CAN P. et al. The nutritive value of live yeast culture (Saccharomyces cerevisiae) and its effect on milk yield, milk composition and some blood parameters of dairy cows. Asian Aust. J. Anim. Sci. v.24, p.1377-1385, 2011.
IBRAHIM, F.; RUVIO, S.; GRANLUND, L. et al. Probiotics and immunosenescence: cheese as a carrier. Immunol. Med.. Microbiol, v.59, p.53-59, 2010.

JUOZAITIENĖ, V.; KUČINSKIENĖ, J.; JUOZAITIS A. et al. Lietuvoje veisiamų juodmargių galvijų veislių itakos somatinių ląstelių kiekiui piene ịvertinimas. Vet. Zootec., v.28, p.83-86, 2004.

KALMUS, P.; ORRO, T.; WALDMANN, A. et al. Effect of yeast culture on milk production and metabolic and reproductive performance of early lactation dairy cows. Acta Vet. Scand., v.51, p.1-7, 2009.

MAAMOURI, O.; SELMI, H.; M'HAMDI, N. Effects of yeast (Saccharomyces cerevisiae) feed supplement on milk production and its composition in Tunisian Holstein Friesian cows. Sci. Agricult. Bohemica, v.45, p.170-174, 2014.

MAENNER, K.; VAHJEN, W.; SIMON, O. Studies on the effects of essential-oil-based feed additives on performance, ileal nutrient digestibility, and selected bacterial groups in the gastrointestinal tract of piglets. $J$.. Anim Sci,. v.89, p.2106-2112, 2011.

MOALLEM, U.; LEHRER, H.; LIVSHITZ, L. et al. The effects of live yeast supplementation to dairy cows during the hot season on production, feed efficiency and digestibility. J. Dairy Sci., v.92, p.343, 2009.

PIRESTANI, A.; BAGHERI, M.J.; HASHEMI, S.M. et al. The effect of selenium, vitamin $\mathrm{E}$ and copper a injection on the somatic cell count and milk compositions in dairy cows. J. Farm Anim. Nutr.Phys., v.9, p.41-49, 2013

ROBINSON, P.H.; GARRETT, J.E. Effect of yeast culture (Saccharomyces cerevisiae) on adaptation of cows to postpartum diets and on lactational performance. $J$. Anim. Sci., v.77, p.988-999, 1999.

SCHWARTZ, D.L.; MULLER, L.D.; ROGERS, G.W. et al. Effect of yeast cultures on performance of lactating dairy cows: a field study. J. Dairy Sci., v.77, p.30733080, 1994.

SZUCS, J.P.; SULI, A.; HALASZ, T. et al. Effect of live yeast culture Saccharomyces cerevisiae on milk production and some blood parameters. Anim. Sci. Biotechnol., v.46, p.40-44, 2013.

WILLIAMS, P.E.V.; TAIT, C.A.G.; INNES, G. et al. Effects of the inclusion of yeast culture (Saccharomyces cerevisiae plus growth medium) in the diet of dairy cows on milk yield and forage degradation and fermentation patterns in the rumen of steers. J. Anim. Sci., v.69, p.3016-3026, 1991. 